\title{
Understanding deforestation and forest fragmenta- tion from a livelihood perspective
}

\author{
Zora Lea Urech', Julie Gwendolin Zaehringer"I, Olivia \\ Rickenbach"II, Jean-Pierre Sorgiv, Hans Rudolf Felberv
}

\author{
Correspondence: \\ Zora Lea Urech \\ HELVETAS Swiss Intercooperation, Switzerland \\ E-mail: urechz@gmail.com
}

\begin{abstract}
Worldwide, forests provide a wide variety of resources to rural inhabitants, and especially to the poor. In Madagascar, forest resources make important contributions to the livelihoods of the rural population living at the edges of these forests. Although people benefit from forest resources, forests are continuously cleared and converted into arable land. Despite long-term efforts on the part of researchers, development cooperation projects and government, Madagascar has not been able to achieve a fundamental decrease in deforestation. The question of why deforestation continues in spite of such efforts remains. To answer this question, we aimed at understanding deforestation and forest fragmentation from the perspective of rural households in the Manompana corridor on the east coast. Applying a sustainable livelihood approach, we explored local social-ecological systems to understand: (i) how livelihood strategies leading to deforestation evolve and (ii) how the decrease of forest impacts on households' strategies. Results highlight the complexity of the environmental, cultural and political context in which households' decision-making takes place. Further, we found crucial impacts of deforestation and forest fragmentation on livelihood systems, but also recognized that people have been able to adapt to the changing landscapes without major impacts on their welfare.
\end{abstract}

\section{RÉSUMÉ}

Partout dans le monde les forêts fournissent une grande variété de ressources aux habitants des régions rurales, particulièrement aux plus pauvres. À Madagascar, les ressources forestières contribuent dans une grande mesure aux moyens d'existence des populations riveraines des forêts. Cependant, bien que les populations tirent parti des ressources de la forêt, les défrichements ne cessent pas et la conversion des zones boisées en terres cultivables se poursuit. Malgré les efforts entrepris depuis des années par les milieux de la recherche et du développement ainsi que par le gouvernement, Madagascar n'a pas encore connu d'inversion du rythme de la déforestation. Pourquoi les défrichements se poursuivent-ils en dépit des efforts entrepris ? C'est à cette question que nous souhaitons apporter une réponse en essayant de comprendre la déforestation et la fragmentation des forêts en prenant en compte les moyens d'existence des ménages ruraux dans le corridor de Manompana, côte Est de Madagascar. En tirant parti de la méthodologie SLA (sustainable livelihood approach), nous avons analysé les systèmes d'existence des populations locales dans le but de comprendre (i) comment évoluent les stratégies de vie impliquant la déforestation et (ii) quel est l'impact de la diminution des surfaces forestières sur les stratégies de vie des ménages. Les résultats mettent en évidence la complexité du contexte environnemental, culturel et politique dans lequel les ménages sont amenés à prendre leurs décisions. La déforestation et la fragmentation des forêts exercent des impacts cruciaux sur les moyens d'existence des ménages. Cependant, il apparait également que les populations sont en mesure de s'adapter à des modifications des paysages sans que cela n'entraîne d'effets majeurs sur leur bien-être. Notre recherche s'est déroulée dans quatre villages, dont deux proches de grands massifs forestiers, les deux autres éloignés des massifs et voisins de fragments de forêts. D'intéressantes différences ont été mises en évidence entre les deux catégories de villages en ce qui concerne l'interface homme-forêt et la perception du rôle joué par la forêt aujourd'hui et à long terme.

\section{INTRODUCTION}

Deforestation of tropical forests around the globe has been happening for tens of thousands of years (Malhi et al. 2014). The underlying drivers have shown to be manifold and interacting with each other (Geist and Lambin 2002). While in many countries the main drivers today are the expansion of large scale agribusiness and a rising demand for forest products by urban populations (Lambin and Meyfroidt 2011), the deforestation frontier of eastern Madagascar is still characterized by smallholders' agricultural expansion for subsistence needs (Zaehringer et al. 2015).

Madagascar's tropical rainforests contain a unique biodiversity (Myers et al. 2000) and provide a broad variety of products and environmental services to local populations and their livelihoods (Kremen et al. 1998). Yet, despite their importance, forests have been used since the first human settlement in Madagascar around 2000 B.C. (Dewar et al. 2013); existing evidence documents a general trend of forest loss (McConnell and Kull 2014) and forest 


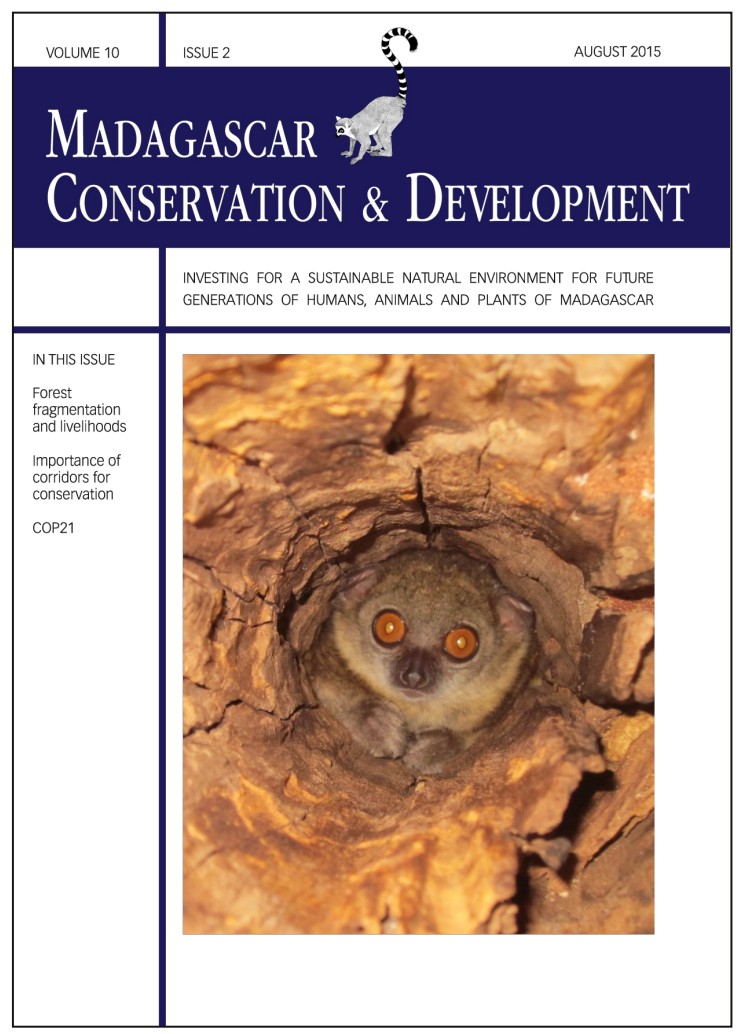

Madagascar Conservation \& Development is the journal of Indian Ocean e-Ink. It is produced under the responsibility of this institution. The views expressed in contributions to MCD are solely those of the authors and not those of the journal editors or the publisher.

All the Issues and articles are freely available at http://www.journalmcd.com

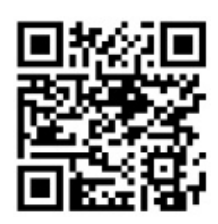

Contact Journal MCD

info@journalmcd.net for general inquiries regarding MCD funding@journalmcd.net to support the journal

Madagascar Conservation \& Development Institute and Museum of Anthropology

University of Zurich

Winterthurerstrasse 190

$\mathrm{CH}-8057$ Zurich

Switzerland

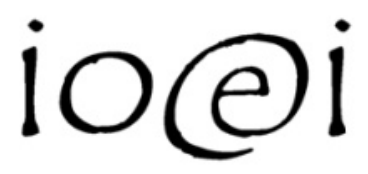

Indian Ocean e-Ink

Promoting African Publishing and Education

www.ioeink.com

Missouri Botanical Garden (MBG)

Madagascar Research and Conservation Program BP 3391

Antananarivo, 101, Madagascar 
fragmentation (Harper et al. 2007). The most recent nation-wide deforestation analyses report a decrease from $0.9 \%$ deforestation per year from 1990-2000 (ibid), to 0.5\% from 2000 to 2005 (MEFT et al. 2007) to $0.4 \%$ from 2005-2010 (ONE et al. 2013). However, local scale forest change studies from the east coast have reported overall increases of forest change and deforestation rates above 1\% (Eckert et al. 2011, Allnutt et al. 2013).

Along the eastern escarpment of Madagascar, currently the main direct cause of deforestation and forest fragmentation is the land use practice of slash-and-burn to cultivate rain-fed hill rice, a system known as tavy in the Malagasy language (Gorenflo et al. 2011). Once the forest is burned, rain-fed hill rice is usually cultivated for only one season, followed by manioc or sweet potato the next (Messerli 2002, Aubert 2008). As a result of the tavy system, soils are heavily washed out and their fertility decreases with every rotation (Pfund 1997, Brand and Pfund 1998). Longer fallow periods maintain better soil fertility. Thus, farmers pursue agricultural expansion as long as forest is available and until enough arable land for long fallow periods is assured (Pollini et al. 2014). At the same time, forest products and resources of remaining forests are used, sold or exchanged. Eventually, however, forests are cleared and converted into complex mosaic landscapes consisting of forest fragments and other mainly agricultural land use types (Pfund 2000, Bennett et al. 2006, Eckert et al. 2011). As described in Urech et al. (2011) forest fragmentation is a dynamic process that reduces larger contiguous forests (called forest massif in this article) into smaller forest patches which become more isolated and increasingly affected by edge effects.

As a consequence, people lose access to forest resources. The reasons why farmers continue to slash-and-burn forested land to grow rain-fed rice, reducing other important forest services and thus undermining part of their own security net, are known to be complex. Multilateral donors and researchers have been engaged for decades in the issue of deforestation in Madagascar, trying to find solutions to stop slash-and-burn agriculture (Messerli 2002, McConnell and Sweeney 2005, Pollini 2009, Freudenberger 2010). Three different approaches have been pursued by these actors as well as the state: (i) attention has been given to testing alternative agricultural practices and finding mechanisms and incentives that would enable land users to adopt those practices (Messerli 2002, Moser and Barrett 2003, Pollini 2009, Freudenberger 2010); (ii) areas reserved for strict nature conservation have been defined (Randrianandianina et al. 2003, Corson 2011) and (iii) a framework for community-based forest management has been implemented by the state with strong support from international donors (Pollini and Lassoie 2011, Bertrand et al. 2014, Corson 2014, Cullman 2015, Rasolofoson et al. 2015).

But deforestation continues nonetheless (ONE et al. 2013) with rural farmers perceived to be the main responsible actors (The World Bank 2013). Behind the direct reason of forest clearance for agricultural use, however, lie a variety of intricately linked indirect economic, political, ecological and social factors influencing farmers' actions (Jarosz 1993, Aubert et al. 2003, Casse et al. 2004, Muttenzer 2010). Meanwhile, it remains poorly understood what role local farmers' socio-cultural realm of attitudes, motivations and behavior plays within this network of driving forces and how deforestation affects their livelihood systems.

The aim of our research was to fill this gap by investigating deforestation and forest fragmentation on the eastern escarpment of Madagascar from a livelihood perspective. The objectives were (i) to identify core and context factors of livelihood systems that lead to agricultural expansion at the expense of natural forests and (ii) to analyze how farmers' livelihood systems are affected by deforestation. In order to understand the evolvement of livelihood systems and strategies, we worked in a transect covering different forest landscapes with different deforestation rates over the past decades. With the aim of obtaining a broad understanding we put our own empirical data in a wider context and complemented it with information from other scientific research articles.

\section{METHODOLOGY}

STUDY SITE. Geographical situation: The Manompana corridor study site (cf. Urech et al. 2012) is located on the east coast of Madagascar in the region of Analanjirofo, district SoanieranaIvongo, and comprises the three municipalities of Manompana, Ambahoabe and Antenina. The Manompana corridor comprises a forested area of around 30,000 ha. From 2007 to 2012 a forest project called KoloAla Manompana was implemented in the corridor, aimed at transferring the management rights of the forest resources to the local communities in order to allow local communities to benefit from sustainable timber harvesting and trade (Urech et al. 2013). The nearest town with a bigger market and connected to the town Manompana with a tarred street is Soanierana-Ivongo. This market is accessible in about 1-2 days walking time from the villages within the Manompana corridor. Only small local markets selling staple foods exist along the tarred street in the Manompana corridor, following the coast. From remote villages, the road is reachable in 7-8 hours walking time, across swampy and hilly landscapes. Annually, Manompana experiences several tropical cyclones (Jury et al. 1999), causing serious damage to agriculture and infrastructure.

Population: All households within the study site are involved in a mixed-production system combining subsistence rice and staple crop cultivation, with market-crop production in some cases. Staple crops (rain-fed rice, manioc, sweet potato) are mainly cultivated with slash-and-burn systems on slopes; if households have access to suitable land, they also cultivate irrigated rice in paddies on valley bottoms. Terraces on slopes for crop cultivation are nonexistent in this zone. For income generation, households sell rice surplus and market crops such as cloves, vanilla, coffee or litchi. Most households cultivate 1-3 land slots in an agroforestry system, combining annual crops (manioc, sweet potato, sugar cane, etc.) and trees (clove, papaya, jackfruit and other fruit and non-fruit trees or bushes). The large majority of the study site's population belongs to the Betsimisaraka ethnic group and around $89 \%$ of households in the Manompana corridor are living below the national poverty line (INSTAT 2011).

SUSTAINABLE LIVELIHOOD APPROACH. In order to gain a ho listic understanding of households' livelihood systems and decision-making processes with respect to deforestation, the Sustainable Livelihood Approach (SLA), as described in Högger and Baumgartner (2004) and Eyhorn (2007), was chosen as the conceptual framework. Compared to other livelihood frameworks, the SLA also takes further dimensions into account, such as the personality characteristics of individuals, their perceptions, emotions, attachments and traditions (Eyhorn 2007). It integrates the analyses of (i) livelihood context factors, (ii) the livelihood core factors and strategy development and (iii) the livelihood outcomes. 
Decisions which lead to deforestation in our study site are taken on the individual level, but can be influenced by factors connected to an ethnical group, the village or even the national level. The SLA is the most adequate approach for the analytical distinction of the broad variety of factors that influence households in our study site.

CONTEXT FACTORS. Context factors are the dynamic external conditions influencing the strategy development process of a household. The SLA divides these factors into opportunities, risks and vulnerabilities; policies, institutions and organizations; and processes and services. We analyzed the 'opportunities' that forests provide that could pose incentives to households to decrease deforestation and forest fragmentation; thus, opportunities that could positively influence households' decision-making process towards a more sustainable forest management.

As 'risks and vulnerabilities' we assessed possible events or realities that can negatively impact livelihoods and drive people to clear forests. Risks are in our case mainly biophysical events (e.g., climatic variability, cyclones, disease). Such risks can lead to vulnerability, depending on the household's ability to cope with them. Similarly, we explored 'policies, institutions, organizations and processes' as well as existent and non-existent farmer support 'services' that could influence households' decisions with respect to deforestation.

CORE FACTORS AND STRATEGY DEVELOPMENT. Personal, emotional and spiritual aspects and orientations are considered the core factors of rural livelihood systems which directly influence the decision-making process of a household (Eyhorn 2007). Core factors and the resulting decision-making process are analyzed with the help of the nine-square mandala (Högger 2004). It can be depicted as a house (Supplementary Material 2) with the three floors representing (i) the orientations at the individual, family and community level in the roof layer, (ii) the interactions of socioeconomic aspects as well as family and individual dimensions and (iii) the household's material resources, its knowledge, skills and emotional values as the household's foundation. Livelihood strategies reflect the range of activities and choices that people make based on the given context and core factors (Eyhorn 2007).

LIVELIHOOD OUTCOMES. Livelihood outcomes are the achie vements of livelihood strategies (Chambers 1995, NADEL 2007). The outcomes then feedback into the livelihood system and influence all its dimensions (context factors, core factors and strategy development). In this study, we aimed to analyze what outcomes result directly from deforestation and forest fragmentation. We worked in villages along a landscape transect covering different forest landscapes; from scarcely forested areas up to densely forested areas.

Based on satellite image interpretation (Rabenilalana 2011) we know that the villages with scarce forested areas lost a large amount of forest resources in the past few decades, due to deforestation. Working along a landscape transect allowed us to understand how the decrease of forest resources influences livelihood systems.

DATA COLLECTION. Research was conducted in four villages

situated at differing distances to the forest massif and with varying forest resource availability (Table 1). We understand the
Table 1. Characteristics of the four studied villages.

\begin{tabular}{|c|c|c|c|c|}
\hline Characteristics & Ambofampana & Maromitety & Bevalaina & Antsahabe \\
\hline $\begin{array}{l}\text { Distance to forest massif } \\
\text { (walking time in h) }\end{array}$ & 0.25 & 0.5 & 2 & 3 \\
\hline $\begin{array}{l}\text { Category of distance to forest } \\
\text { massif }\end{array}$ & near & near & far & far \\
\hline $\begin{array}{l}\text { Forest cover (\% of total } \\
\text { village territory) }\end{array}$ & 86 & 75 & 43 & 21 \\
\hline $\begin{array}{l}\text { Forest fragments ( } \% \text { of forest } \\
\text { cover in village territory) }\end{array}$ & 5 & 20 & 100 & 100 \\
\hline $\begin{array}{l}\text { Number of households living } \\
\text { in village }\end{array}$ & 27 & 26 & 110 & 65 \\
\hline $\begin{array}{l}\text { Market proximity (walking } \\
\text { time in } \mathrm{h} \text { ) }\end{array}$ & 6 & 8 & 2 & 1 \\
\hline Primary school is available & no & no & yes & yes \\
\hline $\begin{array}{l}\text { Age of village: (foundation } \\
\text { year) }\end{array}$ & around 1980 & around 1998 & around 1910 & around 1950 \\
\hline
\end{tabular}

term 'forest massif' as the entire contiguous forest area of the Manompana corridor as well as forest patches with a surface of more than 500 ha and a distance of less than $100 \mathrm{~m}$ to the contiguous forest area. In two villages, Ambofampana and Maromitety, forest still covers $75 \%$ and $86 \%$ of the total village territory, respectively, and villages are situated near the large contiguous forest massif ( $\leq 0.5$ hours walking time). Thus, deforestation and forest fragmentation are assumed to not yet have had an immediate, measurable impact on local livelihoods. The other two villages, Bevalaina and Antsahabe, are situated far from the forest ( $>1$ hour walking time) and have highly fragmented and degraded forest covers of $20 \%$ and $43 \%$, respectively. We know that those villages were also situated near to the forest massif in the past (Green and Sussmann 1990). Thus, deforestation and forest fragmentation are assumed to have already exerted a measurable outcome on local livelihoods. The selection of the two villages near the forest massif and the two villages far from the forest massif allowed us to analyze the direct outcomes of deforestation and forest fragmentation.

In order to limit our investigations to factors and strategies relevant to our research question, we first had to obtain an overall understanding of the local situation. Therefore, open discussions with randomly selected households (total $\mathrm{N}=20$ ) were conducted in the four villages. The discussions covered were related to major problems and key livelihood strategies, the relatedness between people and natural resources and general core and context factors.

Specific details with regard to forest use, deforestation and agricultural expansion were explored using household surveys $(\mathrm{N}=110)$ and focus group discussions $(\mathrm{N}=24)$ with five participants each, disaggregated by gender and wealth. Furthermore, we used participatory and direct observation techniques (Marshall and Rossman 2011). Additional semi-structured interviews with resource persons (e.g., village authorities, village elders) allowed for the triangulation of results (Denzin 1970).

QUALITATIVE AND QUANTITATIVE DATA INTERPRETATION.

Most data have been qualitatively analyzed and interpreted. We grouped and categorized frequent statements from households and focus groups and took different factors such as gender and wealth into account. This allowed us to identify driving forces of current livelihood strategies of local households. In the analysis, we focused mainly on those household strategies that were com- 
mon for a larger part of the population or the collective, rather than on single exceptional strategies. However, strategies representing either a potential benefit or a hazard to the collective (e.g., if an individual household does not respect the common community rules) have also been considered. Since our aim was to provide a comprehensive understanding of farmers' complex realities we complemented our own empirical data with the existing scientific knowledge in this region (Jarosz 1993, Brand and Pfund 1998, Styger et al. 1999, Pfund 2000, Kistler and Messerli 2002, Messerli 2002, Aubert et al. 2003, Kull 2004, Hume 2006, Keller 2008, Pollini 2009, Rakotoarison 2009, Muttenzer 2010, Gorenflo et al. 2011).

To test the correlation of quantitative non-parametrical data in relation to the distance of the four studied villages to the forest massif, the Spearman's rank correlation coefficient was used. To test the difference between the two categories near and far from the forest massif for significance, the Pearson's X2-test was applied.

\section{RESULTS AND DISCUSSIONS}

CONTEXT FACTORS. Opportunities provided by forests: We

found several situations in which forest resources could potentially provide opportunities for simultaneously improving loca livelihoods and preserving the forests. Forests provide diverse products that are used for personal consumption and income generation. All interviewed households depend on timber for house and tool construction, and $79 \%$ of households use edible non-timber forest products (NTFPS) such as tuber, roots, fruits and palm hearts to complement cultivated crops or to enhance cash income (Table 2). This is especially important during the lean season, when households have consumed all rice from the last harvest and not yet harvested again. However, the quantity of edible NTPFs is very small and insufficient to feed a whole household (mean of five persons). Other products used for household consumption are fuel wood, plants for braiding activities and medicinal plants.

Cash income from NTFPs or timber is generated by $47 \%$ $(\mathrm{N}=49)$ of all households. However, the annual income per household generated from forest products is only $0.7 \%$ (1.6 Euro) to 9.3\% (19.7 Euro) of the total annual cash income per household (Urech et al. 2012). This is very low compared to the income generation through forest products in other regions of Madagascar (Shyamsundar and Kramer 1996). In the Manompana corridor NTFPs as well as timber products are sold at prices that do not match the amount of time and effort people spend for harvest and transport. However, the potential of forest products to increase monetary benefit is exploited only to a limited extent. According to Rabenilalana (2011) the high potential of precious woods, mainly of the genus Dalbergia, in the Manompana corridor could, at least for households in the two remote study villages Maromitety and Ambofampana, provide a maximum annual gross

Table 2. Number and percentage of households (out of 110) collecting different categories of forest products for personal consumption.

\begin{tabular}{l|c|c}
\hline \multirow{2}{*}{ Categories of products provided by forests } & \multicolumn{2}{|c}{ Household harvesting } \\
\cline { 2 - 3 } & Number & $\%$ \\
\hline Timber for house construction & 110 & 100 \\
\hline Food (tuber, roots, fruits, palm heart) & 87 & 79 \\
\hline Timber for fuel wood & 81 & 74 \\
\hline Plant leaves for braiding & 81 & 74 \\
\hline Medicinal plants & 23 & 21 \\
\hline
\end{tabular}

income of up to 40 Euro per household, if harvested sustainably. This corresponds to $19 \%$ of the mean annual income per household in the region (Rakotoarison 2009). Thus, the potential is considerably higher than the current earnings from timber trade and NTFPS combined. Nevertheless, limited market access in the two remotest villages hampers the harvest of precious woods for trade. In contrast, in the two villages enjoying better market access, the potential of precious woods is already fully exploited (Rabenilalana 2011). People coming from other territories log the remaining precious woods illegally. For instance, over a ten-day observation period in an accessible forest near one of the study villages, we observed 82 loggers. They transported timber by foot, carrying one timber board on their shoulder. Of the 82 observed loggers, 78 came from neighboring territories. Thus, the benefits from the village's precious wood are lost to households in other territories. Since the management rights for forest resources have not yet been transferred to the villages, they have no legal basis to defend their forest territories.

Risks and Vulnerabilities: Risks in the Manompana corridor are represented by the highly variable environmental (e.g., natural hazards) and economic context (high price fluctuations) as well as by diseases or death of a family member. Due to extreme poverty, households in the study site are particularly vulnerable to these risks, as they are unable to cope with such changes. Examples would be that they cannot hire additional labor to cope with labor shortages or spend money and time to rebuild irrigation systems if a cyclone has destroyed those.

Despite planting rice and other staple crops for subsistence, $60 \%$ of all households have to buy additional food during the lean season because they do not produce enough crops to feed all household members. The majority of households are therefore engaged in casual day labor to generate additional cash. Moser and Barrett (2006) identified dependency on day wages and thus reduced labor availability for the households' own fields as one of the most important factors hindering farmers from improving agricultural practices. In our study site, households do not have enough time, money and flexibility to experiment with risky new technologies and thus prefer to maintain their low-input tavy system. Unfortunately, the main potentiality to escape poverty depends on increasing the productivity of one's one own field (ibid). Thus, households are caught in a poverty trap (Rakodi 2002, Sachs et al. 2004).

Diseases, such as malaria, which is highly prevalent in the region (WHO 2014), constitute another permanent risk as they can fatally reduce labor availability for agricultural activities.

According to the interviewed households, decreasing soil fertility in the whole region further constrains already low yields, and through this increases their vulnerability to natural hazards. Where possible, households thus extend their land under fallow. Cyclones do not only periodically devastate or damage annual rice crops but also destroy irrigation systems and perennial market crops on agroforestry parcels. This deters households from experimenting with permanent agricultural systems and undermines their nutritional and economic security.

With regards to important market crops (e.g., clove trees and vanilla), price fluctuations are another factor reducing motivation to invest household resources into agricultural diversification. Some agroforestry plots were even cleared for this reason. A stable market system that could guarantee a minimum annual income from specific market crops could significantly assist the di- 
versification of households' production and agricultural systems.

Policies, institutions, organizations and processes: According to the policies of the state government, forests are state property and any forest clearance is strictly forbidden. This ban seems to have little effect on local practices. Currently, local customary rights determine forest management and forest clearance in these remote areas. Most commonly, the process of deforestation around our study villages occurs in two steps: (i) forest fragmentation and (ii) forest clearance. By segregating a forest fragment from the large forest massif, households are subsequently considered the rightful owners of the newly created forest fragments next to their arable land, following the local customary right. Consequently, the right to clear the forest fragment is restricted to them (Aubert 2008, Muttenzer 2010, Urech et al. 2011).

As the state forest service has failed to control and assure forest conservation through a centralized forest management policy (Kull 2004), a framework for community-based forest management was established in 1996 (Bertrand et al. 1999). Based on this framework, a local conservation and development project, aimed to establish the necessary local institutions for sustainable and economically beneficial forest management, has been set up in the Manompana corridor. Hence, management rights were transferred to local communities. Local inhabitants should have control of timber logging in allocated areas and can thus benefit directly from the timber trade. The general aim of placing value on existing precious woods, enabling the local population to benefit from them and assuring sustainable forest management through community-based management, is a fundamental opportunity for loca inhabitants. However, a recent study by Rasolofoson et al. (2015) showed that commercial community-based forest management can only contribute to reducing deforestation in Madagascar if institutional shortcomings are solved and local participation is guaranteed.

While decentralized community-based forest management could present an opportunity for local people, it is also highly challenging. If the tavy practice continues as it has until today, sustainable forest management cannot be realized. For households to be able to reduce their dependence on tavy, alternative, productive and sustainable agricultural techniques are needed. Our research shows that officially accepted land tenure rights are also an important barrier preventing households from investing time and labor in the improvement of their agricultural systems. According to the state law very few individuals are recognized landowners. In the two villages near the forest massif, official land ownership does not even exist. Agricultural land for tavy is traditionally distributed among children by their parents. As long as parents have not officially distributed their land, descendants have to cultivate another slot of land every year, allocated by the parents. Thus, many young households have little motivation to invest more time and labor in their cultivation systems, than absolutely necessary, as they cannot be sure to reap the long-term benefits of their investments. Additionally, many households have to lease a slot of land from another owner because they do not own land in their family or because they have immigrated. Several households of the same lineage also cultivate some land areas jointly, in which case no one feels responsible for improving production. This complex situation of land tenure combined with the fact that many farmers do not own land hinders the planting of trees for market crops (stated by $40 \%$ of the farmers), because households can only plant trees if they traditionally own the land.
Thus, households need to own their land to improve yields and to diversify their systems with trees. This, however, can often only be achieved by clearing the forest.

Farmer support services: Manompana's farmers cultivate their hill rice in the same fashion as their ancestors have for centuries. The villages in our study site do not receive support from the government or from NGOs for improving production systems or introducing new agricultural techniques. In regions with better access to roads or rivers, only one organization financed by foreign donors tries to implement a system of intensified rice cultivation (SRI) on irrigated fields. Although experimental studies have shown that, in Madagascar, SRI could increase yields (Barison 2002, Uphoff and Randriamiharisoa 2002), these systems are poorly adopted by local households in ours as well as in other regions (Moser and Barrett 2003). Furthermore, results from interviews and literature review (Hume 2006) show that improved crop yields on irrigated rice fields do not replace the system of tavy on slopes; among other reasons, some of the farmers do simply not have access to irrigated rice fields. To improve current agricultural production and to change the current tavy system, low-investment technologies that can be applied to steep slopes and small plots are necessary. Such innovative technologies were developed by research institutions in Madagascar, e.g., direct seeding on permanent vegetal cover (O. Husson pers. comm.). However, pest and disease control in the absence of chemical inputs is often a major constraint for the success of those technologies (Messerli 2002). Furthermore, households' flexibility to experiment is strongly restricted by the availability of money (Uphoff and Langholz 1998), time and the fear of cyclones. In any case, replacing traditional systems of tavy with a permanent and sustainable cultivation system will require the constant and long-term support of professional technicians (O. Husson pers. comm.).

With regard to forest management, the state forest service is nearly nonexistent in rural areas. The state forest service has one person responsible for the control and monitoring of the whole Analanjirofo region, which includes 1.2 million ha of forests. considering the remoteness and inaccessibility of most of the region, we can conclude that the control of these forests by a single person is impossible. Community-based forest management might be a step in the right direction, but the local population needs stronger support from the forest service in order to develop the necessary skills to manage forest resources on their own and to resolve possible conflicts among stakeholders.

CORE FACTORS AND STRATEGY DEVELOPMENT. Enhance food security through risk minimization: Producing enough crops to feed all household members is the main aim of households in the study site. The current strategy to maintain soil fertility is to keep long fallow periods. As a result, forests are cleared to make new agricultural land available. In villages close to the forest, fallow periods are up to 10 years, while in villages far from the forest fallow periods have decreased to about five years. Compared to the crop yield of tavy systems, traditional irrigated rice cultivation can produce twice as much (Brand 1998). But, as stated by farmers, the latter requires higher time investment to prepare the terrain, to transplant the seedlings and build irrigation systems, and to rebuild them after the damages caused by annual cyclones. Furthermore, farmers explained during interviews that even if irrigated fields produced more than enough rice for personal consumption, they would still continue with tavy, in order to 
diversify their systems and to reduce the risk of crop failure due to cyclones. Tavy is known to be a flexible, low-intensive and cyclone adapted system in other regions (ibid). Households stated that they prefer to grow food in slash-and-burn systems in order to enhance food security in the short-term. Moreover, due to the rugged topography, $34 \%$ of households in the remote villages do not have access to suitable land to cultivate irrigated rice.

Attain customary land ownership through deforestation: As described above, according to customary law, households can become traditional owners of forest fragments and land through clearing forests. Especially for poorer households or immigrants this is often the only possibility to attain land ownership. Thus, many landless people move to very remote regions where they can find a contiguous forest massif not yet owned by other families. When more land is needed for future descendants or if soi fertility in the tavy system is decreasing, households begin to clear their own forest fragments to bring the forest soil into production.

Attachment to ancestors: The system of tavy, as we observed in the Manompana corridor, is an integral part of the culture pertaining to the region's dominant ethnic group of the Betsimisara$k a$. This is the case also for other regions of eastern Madagascar (Bertrand and Lemalade 2008). Keller (2008) observed on the Masoala peninsula that the conversion of forest into arable land is considered essential for ensuring a connection between the ancestors and future generations. Descendants should be rooted in the land of the ancestors by cultivating their land (ibid), and forests are ancestral land. According to long tradition, deforestation and subsequent cultivation are a means of guaranteeing this connection.

Another important element of the Betsimisaraka's culture, which could be observed in our study site as well as in other regions of the eastern escarpment (Kistler and Messerli 2002), is the duty to honor the ancestral way of life and continue with the same systems of cultivation as were used in the past. Thus, these traditions hinder households from experimenting with new technologies, as they provoke social pressure from other villagers. Many taboos are linked to cultivation systems, especially tavy, and village chiefs and other village members control the application of taboos. Village chiefs in our study site noted that if households renege on particular taboos, village authorities must sanction them. This was the case if farmers applied new technologies or if they did not respect the two to three days (according to the individual village) per week during which farmers are not allowed to work in their agricultural fields.

Individual, family and community orientation towards forest conservation: 62 households $(N=110)$ claimed to be very motivated to conserve their remaining forest fragments and to stop forest clearance by tavy. These were mainly wealthier households who already own large areas of land and are aware of the finiteness of natural resources (Urech et al. 2012). To enhance sustainable forest management, such individual interests preserving forest fragments must become collective concerns; otherwise communal interventions and regulations will fail (Ostrom 1999).

However, according to Cole (2001), the mobilization of the Betsimisaraka into acting as a community has always been difficult, which is in line with Berkes (2004) who showed that the concept of a 'community' is very heterogeneous. Families are more strongly attached to their lineages than to spatial organizations or administrative structures imposed by the state. Although we could identify communal regulations that predict a sustainable use for some NTFPs (e.g., Pandanaceae) we did not observe any community-based approaches with regard to sustainable forest management as a whole. Forests are ancestral land and accordingly managed by lineage and clans, as observed in other regions of Madagascar (Kull 2004, Muttenzer 2006). Thus, while bans on the clearance of certain forest fragments or restrictions on the use of forest products exist, they are based on clan or lineage-specific taboos. We found several such remaining forests near the two villages close to the forest massif. In the two other villages, however, most of these so called 'sacred forests' have already been cleared by lineages that do not have to respect the specific taboo. Therefore, lineage-specific taboos are no guarantee for forest protection. Moreover, taboos can change within a family as resources become scarce (Fedele et al. 2011, Urech et al. 2011). This shows that orientations which could enhance forest conservation differ between lineages but can be adapted to changing circumstances over time.

Awareness of forest depletion: While exploring households' decision-making processes, we questioned people about the consequences of a landscape without forests on their livelihood systems. Most households living close to the forest massif are unable to envision a landscape without forests and are thus not aware of forest resource's finiteness. Households living far from the forest massif are significantly more aware of the exhaustibility of forest resources. They have witnessed the large-scale disappearance of forest resources and the consequent scarcity of resources. The further households were living from the forest massif, the more able they were to name forest products existing in the past from the village territory (Spearman's correlation, $r=0.305, N=88, p=0.004$ ). We also asked households if they would agree to a prohibition of the expansion of tavy practice on natural forest in their village territory. The further away the village is from the forest massif, the higher the agreement is to prohibit such extensions in order to preserve remaining forests (Spearman's correlation, $r=0.557, \mathrm{~N}=96, \mathrm{p}<0.001$ ).

LIVELIHOOD OUTCOMES AND THEIR INFLUENCE ON LIVELI HOOD SYSTEMS. The number of households collecting timber and NTFPs for personal use does not differ significantly between households living near or far from the forest massif (Table 3). However, there is a significantly higher proportion of households living far from the massif who gain cash with timber (Pearson's $\mathrm{X} 2=7.08, \mathrm{df}=1, \mathrm{p}=0.008$ ). This can be explained by market accessibility, rather than by proximity to the forest massif. Near the forest massif, people have better access to precious woods but cannot exploit it because of market inaccessibility. In contrast, the number of households selling NTFPS is significantly higher close to the massif (Pearson's $X 2=15.07, d f=1, p<0.001$ ). This is due to the proximity to the forests where NTFPs are still available in high quantities and are of good quality. Moreover, NTFPs are easier to carry over long distances to markets than timber.

Table 3. Number of households (out of 110) collecting timber and NTFPs for personal use or trade, separated by the distance to the forest massif (near and far).

\begin{tabular}{l|cc|cc}
\hline & \multicolumn{2}{|c|}{ Near forest massif } & \multicolumn{2}{c}{ Far from forest massif } \\
\hline Answers from questioned households $(\mathrm{N}=110)$ & Number & $\%$ & Number & $\%$ \\
\hline Timber harvest for personal use & 48 & 100 & 62 & 100 \\
\hline NTFP harvest for personal use & 47 & 98 & 52 & 84 \\
\hline Timber harvest for trade & 7 & 15 & 24 & 38 \\
\hline NTFP harvest for trade & 27 & 59 & 9 & 14 \\
\hline
\end{tabular}


Households collect a decreasing number of different NTFPs for personal use or trade the further they live from the forest massif (Spearman's correlation, $r=-0.777, \mathrm{~N}=102, \mathrm{p}<0.001$ ) (Figure 1). One reason for this decrease is obvious: the less forest area that exists in the village territory, the less people can collect NTFPS. Another reason is that people living near the forest massif must invest less time in searching for NTFPs that exist only in the massif (e.g., wild pigs, lemurs). A third reason is the decreasing quality of products, as is the case with tsiriky (Pandanus guillaumetii), for example. This plant is still well-represented in fragments surrounding villages far from the massif, but due to human population pressure plants of suitable quality for mat weaving are becoming rare. As a result, people do not collect tsiriky anymore and replace it with Lepironia mucronata, a Cyperaceae growing in marshlands (Fedele et al. 2011).

Close to the forest massif all households still have access to forest products and there is a collective orientation of all households to apply the customary rights of open access to all forest products. In the villages far from the forest massif we could observe growing dissatisfaction with regard to open access to forest products. Fragment owners fear that forest resources will not satisfy their future needs, especially for fuel and timber. Some farmers also began to ask for money from outsiders who want to cut timber in their fragments. Their dissatisfaction may influence the social cohesion of the community and has already resulted in social conflicts among villagers.

Households living far from the forest massif have found ways to adapt their livelihood strategies to the new context of degraded and limited remaining forest resources. Some forest products are replaced with alternative products growing in land use types other than forests. However, the use of alternative products often results in a forfeit of quality. For instance, the leaves of ravintsira (Dypsis sp.) a palm species growing in forests (Byg and Balslev 2001), are used to build house roofs, but can be replaced by the leaves of ravinala (Ravenala sp.), growing in secondary vegetation. Ravinala is less resistible to rain and lasts only a few years. Other forest products such as high quality timber, certain edible roots or meat (e.g., from lemurs) must be bought at local markets because they are no longer available in the vicinity of the study villages. This adaptation of livelihood strategies has a significant outcome on livelihood systems: if products have to be bought, households become more dependent on cash availability through income generation activities. In turn, this has a negative influence on the so-

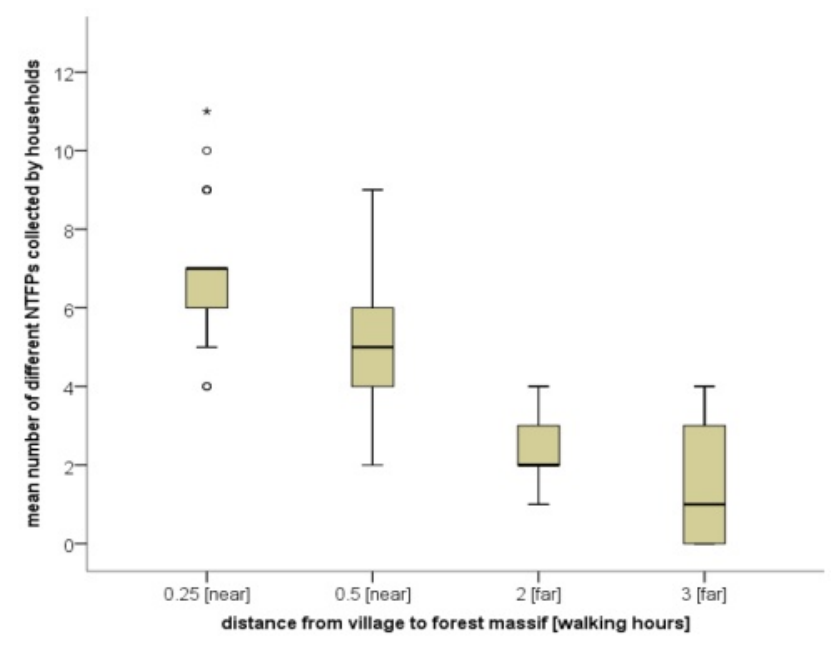

Figure 1. Mean number of different NTFPs collected per household and separated according to the distance of the village from the forest massif. cial cohesion between villagers. Many households noted that in the past, families helped each other to cultivate their fields. Nowadays, people want to be paid for their work. Forest products such as tubers or fruits are replaced by products growing in crop and agroforestry systems. As a consequence, with decreasing availability of forest products, the increasing diversification of crop and agroforestry systems can be observed. Products from agroforestry systems can also be sold and allow households to increase their cash income. However, as described above, major obstacles for the expansion of agroforestry systems include the risk of cyclone damage, limited market access to sell fruits, and the high price fluctuations of the market crops.

Research results show that households living close to the forest massif depend more on forest resources than households living far from the massif. To explore households' own perception about their dependency on forests, we asked them "What are the consequences of deforestation on your personal well-being?"; $59 \%$ of all answering families see negative consequences (details described in Urech et al. 2013). The most frequent negative consequences cited are that families will need more time to find necessary products, that income generation through timber and NTFP will decrease and that forest products will be of lower quality. However, our concluding question after the analysis of the specific consequences was: "Could you survive without forests?", and $79 \%(\mathrm{~N}=19)$ of the households living closest to the forest massif confirmed that they could survive without forests (Figure 2). Considering only the three villages within 0.2 to 2 hours walking distance of the forest massif, the percentage of people answering with "no" increased significantly and correlated inversely with distance (Spearman's correlation, $r=-0.324, n=67, p=0.008$ ) to the massif. Surprisingly, in the fourth village furthest from the massif, $85 \%(N=23)$ answered again with yes, they could survive without forests.

We associate the predominant perception close to the forest massif of not being dependent on forest resources with a low awareness of forest scarcity. Moreover, the strategy of households living close to the massif is still to clear forests to gain more arable land. This shows that for the decision-making process, forests are not perceived as very important in terms of their products, but rather as a future land resource for agriculture. However, in the village furthest from the forest massif, people are aware of the consequences of deforestation but have learned that they are able to survive with very limited forest resources.

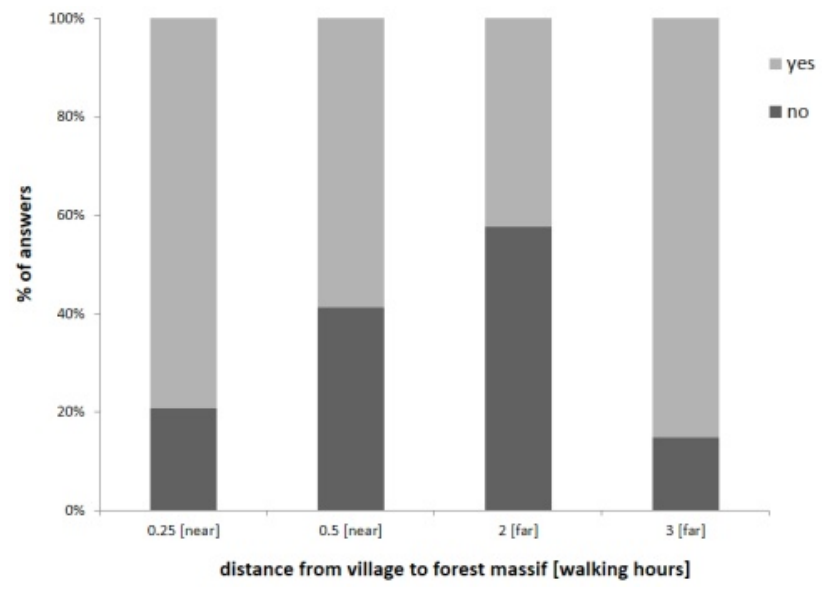

Figure 2. Answers to the question: "Could you survive without forests?", separated according to the distance of the village from the forest massif. 


\section{CONCLUSION}

The current livelihood strategies of local households are based on the traditional tavy rice cultivation practice, which leads to deforestation and forest fragmentation. The opportunities arising from exploitable forest resources do not seem beneficial enough to make households change their livelihood strategies to preserve those resources for the future. Although there is an existing potential for the commercialization of precious woods and NTFPS, currently it cannot be exploited due to nonexistent infrastructure, limited market access, a lack of an institutional framework and the absence of regulations that would allow a legal, sustainable and profitable trade in forest resources. In addition, the very slow growth of Dalbergia species as well as the currently intensive illegal logging (Randriamalala and Liu 2010) considerably reduce the potential for an ecologically sustainable exploitation.

Forest products are used as long as they are available. Once forest resources become scarce, people demonstrate the flexibility to adapt. Products are substituted and cultural values and rules are adapted accordingly. Nevertheless, it must be noted that all of our studied villages still have forest resources left. The tavy rotation cycle in these villages is $5-10$ years, whereas it has decreased to three years in other regions of Madagascar (Styger et al. 1999, Hume 2006). Households in our study villages have not yet experienced the consequences of the high soil erosion and degradation that have occurred elsewhere on the island. If deforestation continues, the environmental consequences are likely to negatively impact agricultural production systems in the Manompana corridor in the future.

In order to improve the overall sustainability of livelihood systems and wellbeing of households, current agricultural practices should be transformed into permanent cultivation systems that (i) do not undermine soil fertility, (ii) produce enough crops to feed the growing local population and (iii) can co-exist with the remaining forests. Such improved production systems have to be designed and tested in close collaboration with the concerned households and farmer communities, so that the new practices are in line with livelihood strategies and the common obstacles to adoption are considered. Those obstacles are manifold: Households' current livelihood strategies are based on experience and risk management, and may be wise with regard to their biophysical environment.

The tavy practice is flexible and less vulnerable to damages caused by cyclones than are irrigated rice fields (Brand 1998, Laney 2002). The fact that tavy is deeply anchored in Betsimisaraka culture and that innovation often is hampered by social pressure, adds an additional hurdle to the implementation of innovative technologies. Unsecured tenure rights are another obstacle for local households to diversify their traditional agricultural systems. Moreover, the high vulnerability of local households severely limits their motivation to experiment with and to invest time and resources in new agricultural practices. Therefore, any new technologies that are proposed should be low-input and adaptable to local conditions, and not too susceptible to cyclones. Households need access to additional and alternative income sources in order to allow them a minimal flexibility to experiment with innovative technologies. Moreover, a long-lasting collaboration between local traditional authorities, extension workers and agronomists is needed to adapt new technologies to given cultural factors and social circumstances and to involve local authorities in a common decision-making process.
In order to guarantee forest conservation, it is recommendable to harness the existing potential of forest resources in such a way that preserving forests becomes a more attractive option to households than clearing them. An institutional framework encouraging the sustainable use of these opportunities is vital. The community-based forest management project which was implemented in the Manompana corridor was a significant first step in the direction of beneficial and sustainable forest management and the support of local institutions created in the course of the project should be maintained to ensure their continuity. Income generation from forest products would also allow households to have an alternative source of cash income, which in turn would give them more flexibility to invest in agricultural improvement. It would thus be possible to ensure the future availability of forest resources and environmental services to a greater extent. However, community-based forest management can only be realized if livelihood systems as a whole are considered. Innovative approaches that address the current problems of rural livelihood systems and that can cope with the complexity of rural peoples' realities are needed. The forestry sector should develop a more integrative landscape planning approach, widening the scope to include agricultural land use.

Our research shows that to counter the strategies leading to deforestation, changing one context factor or simply improving one sector of peoples' realities will not be sufficient. National and international organizations are confronted with considerable challenges. They need a broad understanding of the different factors that influence people's decision-making process, including socioeconomic, ecological, and cultural aspects. However, the local population must also contribute to the betterment of its current situation. While the ability of local households to change their livelihood strategies is limited by their given context, their willingness to change some of their habits, customs and traditions is indispensable for a successful collaboration between different institutions and the local population. A holistic understanding is the necessary starting point for further investigations and future interventions. However, particularly in regard to understanding, aspects of cultural attachments, and the dilemma between collective orientation and individual innovation, will require further research by anthropologists or even psychologists.

\section{ACKNOWLEDGEMENTS}

This work was supported by the Swiss Agency for Development and Cooperation (SDC) and the Research Fellow Partnership Programme (RFPP). We would like to thank AIM (Association Intercooperation Madagascar), the KoloAla Manompana team and in particular the local households who made this research possible by sharing their thoughts and information with us, Erin Gleeson for proof-reading, as well as the reviewers for their valuable comments.

\section{REFERENCES}

Allnutt, T. F., Asner, G. P., Golden, C. D. and Powell, G. V. N. 2013. Mapping recent deforestation and forest disturbance in northeastern Madagascar. Tropical conservation Science 6, 1: 1-15.

Aubert, S. 2008. Autorités coutumières et régulation sociale. In: Déforestation et Systèmes Agraires à Madagascar. Les Dynamiques des Tavy sur la Côte Orientale. S. Aubert, S. Razafiarison \& A. Bertrand (eds.), pp 107-132. CIRAD Montpellier. 
Aubert, S., Razafiarison, S. \& Bertrand, A. (eds.) 2003. Déforestation et Systèmes Agraires à Madagascar. Les Dynamiques des Tavy sur la Côte Orientale. $\mathrm{Cl}$ RAD, Montpellier.

Barison, J. 2002. Evaluation of nutrient uptake and nutrient-use efficiency of SRI and conventional rice cultivation methods in Madagascar. In: Assessments of the System of Rice Intensification (SRI): Proceedings of an International Conference, Sanya, China, 1-4 April 2002, Uphoff, et al. (eds.), pp 143-147. CIIFAD, Ithaca, NY, USA

Bennett, A. F., Radford, Q. and Haslem, A. 2006. Properties of land mosaics: Implications for nature conservation in agricultural environments. Biological Conservation 133, 2: 250-264. (doi:10.1016/j.biocon.2006.06.008)

Berkes, F. 2004. Rethinking community-based conservation. Conservation Biology 18, 3: 621-30. (doi:10.1111/j.1523-1739.2004.00077.x)

Bertrand, A. \& Lemalade, J.-L. 2008. Riziculture de tavy et sécurité alimentaire. In: Déforestation et Systèmes Agraires à Madagascar. In : Les Dynamiques des Tavy sur la Côte Orientale. S. Aubert, S. Razafiarison \& A. Bertrand (eds.), pp 75-83. CIRAD, Montpellier.

Bertrand, A., Babin, D. \& Nasi, R. 1999. L'adaptation de l'aménagement forestier à des situations diverses. Bois et Forêts des Tropiques 261, 3: 39-49.

Bertrand, A., Aubert, S. \& Montagne, P. 2014. Madagascar, politique forestière: BiIan 1990-2013 et propositions. Madagascar Conservation \& Development 9 , 1:20-30. (doi:10.4314/mcd.v9i1.4)

Brand, J. 1998. Das Agro-ökologische System am Ostabhang Madagaskars. Ressourcen- und Nutzungsdynamik unter Brandrodung. CDE, Geographisches Institut der Universität Bern, Bern.

Brand, J. and Pfund, J. L. 1998. Site- and watershed-level assessment of nutrient dynamics under shifting cultivation in eastern Madagascar. Agriculture, Ecosystems \& Environment 71, 1-3: 169-183. (doi:10.1016/S01678809(98)00139-X)

Byg, A. and Balslev, H. 2001. Traditional knowledge of Dypsis fibrosa (Arecaceae) in Eastern Madagascar. Economic Botany 55, 2: 263-275. (doi:10.1007/BF02864564)

Casse, T., Milhoj, A., Ranaivoson, S. and Romuald Randriamanarivo, J. 2004. Causes of deforestation in southwestern Madagascar: What do we know? Forest Policy and Economics 6, 1: 33-48. (doi:10.1016/S1389-9341(02)00084-9)

Chambers, R. 1995. Poverty and livelihoods: Whose reality counts? Environment and Urbanization 7, 1: 173-204. (doi:10.1177/095624789500700106)

Cole, J. 2001. Forget Colonialism? Sacrifice and the Art of Memory in Madagascar. University of California Press, Berkeley, CA.

Corson, C. 2011. Territorialization, enclosure and neoliberalism: non-state influence in struggles over Madagascar's forests. The Journal of Peasant Studies 38, 4: 703-726. (doi:10.1080/03066150.2011.607696)

Corson, C. 2014. Conservation politics in Madagascar. The expansion of protected areas. In: Conservation and Environmental Management in Madagascar. I. R. Scales (ed.), pp 193-215. Earthscan Conservation and Development Series. Routledge, London and New York.

Cullman, G. 2015. Community forest management as virtualism in northeastern Madagascar. Human Ecology 43, 1: 29-41. (doi:10.1007/s10745-015-9725-5)

Denzin, N. 1970. The Research Act: A Theoretical Introduction to Sociological Methods. Aldine, Chicago, IL.

Dewar, R. E., Radimilahy, C., Wright H. T., Jacobs, Z., Kelly, G. O. and Berna, F. 2013. Stone tools and foraging in northern Madagascar challenge holocene extinction models'. Proceedings of the National Academy of Sciences of the USA 110, 31: 12583-12588. (doi:10.1073/pnas.1306100110)

Eckert, S., Rakoto Ratsimba, H., Rakotondrasoa, L. O., Rajoelison, L. G. and Ehrensperger, A. 2011. Deforestation and forest degradation monitoring and assessment of biomass and carbon stock of lowland rainforest in the Analanjirofo region, Madagascar. Forest Ecology and Management 262, 11 1996-2007. (doi:10.1016/j.foreco.2011.08.041)

Eyhorn, F. 2007. Organic Farming for Sustainable Livelihoods in Developing Countries? The Case of Cotton in India. vdf Hochschulverlag AG an der ETH Zürich, Zürich.

Fedele, G., Urech, Z. L., Rehnus, M. and Sorg, J.-P. 2011. Impact of women's harvest practices on Pandanus guillaumetii in Madagascar's lowland rainforests. Economic Botany 65, 2: 158-168. (doi:10.1007/s12231-011-9157-0)
Freudenberger, K. 2010. Paradise Lost? Lessons from 25 Years of USAID Environment Programs in Madagascar. Unpub. report prepared by International Resources Group, Washington.

Geist, H. J. and Lambin, E. F. 2002. Proximate causes and underlying driving forces of tropical deforestation. Bioscience 52, 2: 143-150. (doi: 10.1641/00063568(2002)052[0143:PCAUDF]2.0.CO;2)

Gorenflo, L. J., Corson, C., Chomitz, K. M., Harper, G., Honzák, M. and Özler, B. 2011 Exploring the association between people and deforestation in Madagascar. In: Human Population. R. P. Cincotta and L. J. Gorenflo (eds.), pp 197-221. Springer Berlin, Heidelberg.

Green, G. M. and Sussmann, R. W. 1990. Deforestation history of the eastern rain forest of Madagascar from satellite images. Science 248: 212-215. (doi:10.1126/science.248.4952.212)

Harper, G. J., Steininger, M. K., Tucker, C. J., Juhn, D. and Hawkins, F. 2007. Fifty years of deforestation and forest fragmentation in Madagascar. Environmental Conservation 34, 4: 325-333. (doi:10.1017/s0376892907004262)

Högger, R. 2004. Understanding livelihood systems as complex wholes. In: In Search of Sustainable Livelihood Systems. Managing Resources and Change. R. Baumgarter and R. Högger (eds.), pp 35-54. Sage Publications New Delhi, Thousand Oaks, London.

Högger, R. and Baumgartner, R. 2004. The RLS approach in the project cycle management. In: In Search of Sustainable Livelihood Systems. Managing Resources and Change. R. Baumgarter and R. Högger (eds.), pp 351-364. Sage Publications, New Dehli, Thousand Oaks, London.

Hume, D. W. 2006. Swidden agriculture and conservation in eastern Madagascar: Stakeholder perspectives and cultural belief systems. Conservation and Society 4, 2: 287-303.

INSTAT. 2011. Enquête Périodique auprès des Ménages 2010. Unpub. Rapport Principal. INSTAT, Antananarivo, Madagascar.

Jarosz, L. 1993. Defining and explaining tropical deforestation: shifting cultivation and population growth in colonial Madagascar (1896-1940). Economic Geography 69, 4: 366-379. (doi:10.2307/143595)

Jury, M. R., Pathack, B. and Parker, B. 1999. Climatic determinants and statistica prediction of tropical cyclone days in the southwest Indian Ocean. Journal of Climate 12, 6: 1738-1746. (doi:10.1175/15200442(1999)012<1738:CDASPO>2.0.CO;2)

Keller, E. 2008. The banana plant and the moon: Conservation and the Malagasy ethos of life in Masoala, Madagascar. American Ethnologist 35, 4: 650-664. (doi:10.1111/j.1548-1425.2008.00103.x)

Kistler, P. and Messerli, P. 2002. Livelihood strategies, knowledge management and innovation in slash-and-burn cultivation system in Madagascar. In: Local Environmental Management in a North-South Perspective. M. Flury and U. Geiser (eds.), pp 237-253. vdf Hochschulverlag, Zürich, Singen.

Kremen, C., Raymond, I. and Lance, K. 1998. An interdisciplinary tool for monitoring conservation impacts in Madagascar. Conservation Biology 12, 3 : 549-563. (doi:10.1111/j.1523-1739.1998.96374.x)

Kull, C. A. 2004. Isle of fire. The Political Ecology of Landscape Burning in Madagascar. The University of Chicago Press, Chicago, London.

Lambin, E. F. and Meyfroidt, P. 2011. Global Land use change, economic globalization, and the looming land scarcity. Proceedings of the National Academy of Sciences of the USA 108, 9: 3465-3472. (doi:10.1073/pnas.1100480108)

Laney, R. M. 2002. Disaggregating induced intensification for land-change analysis: a case study from Madagascar. Annals of the Association of American Geographers 92, 4: 702-726. (doi:10.1111/1467-8306.00312)

Malhi, Y., Gardner, T. A., Goldsmith, G. R., Silman, M. R. and Zelazowski, P. 2014. Tropical forests in the anthropocene. Annual Review of Environment and Resources 39, 1: 125-159. (doi:10.1146/annurev-environ-030713-155141)

Marshall, C. and Rossman, G. B. 2011. Designing Qualitative Research. SAGE, LoS Angeles, London, and New Dehli.

McConnell, W. J. and Kull, C. A. 2014. Deforestation in Madagascar: debates over the island's forest cover and challenges of measuring forest change. In: Conservation and Environmental Management in Madagascar. I. R. Scales (ed.), pp 67-104. Earthscan Conservation and Development Series. Routledge, London and New York. 
McConnell, W. J. and Sweeney, S. P. 2005. Challenges of forest governance in Madagascar. The Geographical Journal 171, 3: 223-238. (doi:10.1111/j.14754959.2005.00162.x

MEFT (Ministère de l'Environnement, des Forêts et du Tourisme), USAID \& C (Conservation International). 2009. Evolution de la Couverture de Forêts Naturelles à Madagascar, 1990-2000-2005. Madagascar, Antananarivo.

Messerli, P. 2002. Alternatives à la Culture sur Brûlis sur la Falaise Est de Madagascar. Stratégie en Vue d'une Gestion plus Durable des Terres. Unpub. Report to Centre pour le Développement et l'Environnement (CDE), Université de Berne, Berne.

Moser, C. M. and Barrett, C. B. 2003. The disappointing adoption dynamics of a yield-increasing, low external-input technology: the case of SRI in Madagascar. Agricultural Systems 76, 3: 1085-1100. (doi:10.1016/S0308$521 \times(02) 00041-0)$

Moser, C. M. and Barrett, C. B. 2006. The complex dynamics of smallholder technology adoption: the case of SRI in Madagascar. Agricultural Economics 35 3: 373-388. (doi:10.1111/j.1574-0862.2006.00169.x)

Muttenzer, F. 2006. Déforestation et Droit Coutumier à Madagascar. L'Historicité d'une Politique Foncière. Université de Genève, Genève.

Muttenzer, F. 2010. Déforestation et droit coutumier à Madagascar. Les perceptions des acteurs de la gestion communautaire des forêts. Karthala \& Institut des Hautes Études Internationales et du Développement, Paris, Genève.

Myers, N., Mittermeier, R. A., Mittermeier, C. G., Fonseca, G. and Kent, J. 2000. Biodiversity hotspots for conservation priorities. Nature 403: 853-858. (doi:10.1038/35002501)

NADEL. 2007. Working with a Sustainable Livelihood Approach. <www.poverty wellbeing.net> accessed 25 August 2014

ONE (Office National pour l'Environnement), DGF (Direction Générale des Forêts), $\mathrm{Cl}$ (Conservation International), FTM (Foiben-Taosarintanin'i Madagasikara) \& MNP (Madagascar National Parks). 2013. Evolution de la couverture de forêts naturelles à Madagascar 2005-2010. Antananarivo, Madagascar.

Ostrom, E. 1999. Self-governance and forest resources. Occasional Paper No. 20. CIFOR, Bogor, Indonesia.

Pfund, J.-L. 1997. Culture sur brûlis: bilan de nutriments et successions écologiques. Cahier Terre Tany 6: 68-88.

Pfund, J.-L. 2000. Culture sur Brûlis et Gestion des Ressources Naturelles. Evolution et Perspective des Trois Terroirs Ruraux du Versant Est de Madagascar. ETH Zurich and EPF Lausanne.

Pollini, J. 2009. Agroforestry and the search for alternatives to slash-and-burn cultivation: From technological optimism to a political economy of deforestation. Agriculture, Ecosystems \& Environment 133, 1-2: 48-60. (doi:10.1016/j.agee.2009.05.002)

Pollini, J. and Lassoie, J. P. 2011. Trapping farmer communities within global environmental regimes: The case of the GELOSE legislation in Madagascar. Society and Natural Resources 24, 8: 814-830. (doi:10.1080/08941921003782218)

Pollini, J., Hockley, N., Muttenzer, F. D. and Ramamonjisoa, B. S. 2014. The transfer of natural resource management rights to local communities. In: Conservation and Environmental Management in Madagascar. I. R. Scales (ed.), pp 172-192. Earthscan Conservation and Development Series. Routledge, London and New York

Rabenilalana, M. 2011. Fragmentation et Dynamique du Paysage de la Forêt Dense Humide de Basse Altitude. Cas de Manompana - Nord-Est de Madagascar. Département des Eaux et Forêts, Université d'Antananarivo, Antananarivo

Rakodi, C. 2002. A capital assets framework for analysing household livelihood strategies: implications for policy. Development Policy Review 17, 3 315-342. (doi:10.1111/1467-7679.00090)

Rakotoarison, H. H. 2009. Revenus Ruraux et Compensation pour Services Environnementaux. Cas du Corridor Forestier de Manompana, District de Soanierana Ivongo. Département des Eaux et Forêts, Ecole Supérieure des Sciences Agronomiques. Université d'Antananarivo, Antananarivo.

Randriamalala, H. and Liu, Z. 2010. Rosewood of Madagascar: between democracy and conservation. Madagascar Conservation \& Development 5, 1: 11-22. (doi:10.4314/mcd.v5i1.57336)
Randrianandianina, B. N., Andriamahaly, L. R., Harisoa, F. M. and Nicoll, M. E. 2003. The role of the protected areas in the management of the island's biodiversity. In: The Natural History of Madagascar. S. M. Goodmann and J. P. Benstead (eds.), pp 1423-1432. The University of Chicago Press, Chicago and London.

Rasolofoson, R. A., Ferraro, P. J., Jenkins, C. N. and Jones, J. P. G. 2015. Effectiveness of community forest management at reducing deforestation in Madagascar. Biological Conservation 184: 271-277. (doi:10.1016/j.biocon.2015.01.027)

Sachs, J. D., McArthur, J. W., Schmidt-Traub, G., Kruk, M., Bahadur, C., Faye, M. and Gordon, M. 2004. Ending Africa's poverty trap. Brookings Papers on Economic Activity 200, 1: 117-216. (doi:10.1353/eca.2004.0018)

Shyamsundar, P. and Kramer, R. A. 1996. Tropical forest protection: an empirical analysis of the costs borne by local people. Journal of Environmental Economics and Management 31, 2: 129-144. (doi:10.1006/jeem.1996.0036)

Styger, E., Rakotoarimanana, J., Rabevohitra, R. and Fernandes, E. 1999. Indigenous fruit trees of Madagascar: potential components of agroforestry systems to improve human nutrition and restore biological diversity. Agroforestry Systems 46, 3: 289-310. (doi:10.1023/A:1006295530509)

The World Bank. 2013. Madagascar country environmental analysis (CEA) - Taking stock and moving forward. The World Bank, Washington D.C. Available at http://ow.ly/R9jzl

Uphoff, N. and Langholz, J. 1998. Incentives for avoiding the tragedy of the commons. Environmental Conservation 25, 3: 251-261.

Uphoff, N. and Randriamiharisoa, R. 2002. Reducing water use in irrigated rice production with the Madagascar System of Rice Intensification. In: WaterWise Rice Production: Proceedings of the International Workshop on Water Wise Rice Production, 8- 11 April 2002. B. A. M. Bouman, et al. (eds.), pp 71-87. International Rice Research Institute, Los Banos, Philippines.

Urech, Z. L., Rabenilalana, M., Sorg, J.-P. and Felber, H. R. 2011. Traditional use of forest fragments in Manompana, Madagascar. In: Collaborative Governance of Tropical Landscapes. C. J. P. Colfer and J.-L. Pfund (eds.), pp 131-155. Earthscan. London.

Urech, Z. L., Felber, H. R. and Sorg, J.-P. 2012. Who wants to conserve remaining forest fragments in the Manompana corridor? Madagascar Conservation \& Development 7, 3: 22-29. (doi:10.4314/mcd.v7i3.6)

Urech, Z. L., Sorg, J.-P. and Felber, H.-R. 2013. Challenges for community-based forest management in the KoloAla site Manompana. Environmental Management 51, 3: 602-615. (doi:10.1007/s00267-012-0011-7)

WHO. 2014. Madagascar: Health Profile. Available at: <http://www.afro.who.int/en/madagascar/country-health-profile.html>

Zaehringer, J. G., Eckert, S. and Messerli, P. 2015. Revealing regional deforestation dynamics in north-eastern Madagascar - Insights from multi-temporal land cover change analysis. Land 4, 2: 454-474. (doi:10.3390/land4020454)

\section{SUPPLEMENTARY MATERIAL.}

Available online only.

Figure S1. The Sustainable Livelihood Approach, adapted from NADEL (2007).

Figure S2. The nine-square mandala adapted from Högger (2004).

S3. Questionnaires and guidelines for discussions. 